\title{
Military Operations
}

\author{
Harald Høiback
}

\section{Contents}

Introduction

A History of Military Thought: A Long and Winding Road Towards a Conceptualization of

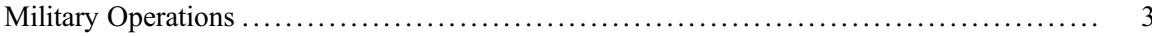

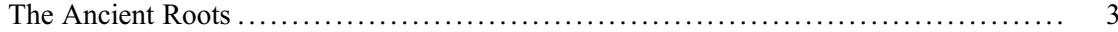

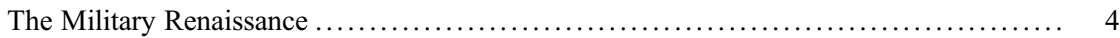

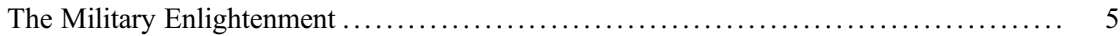

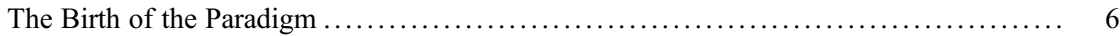

A Counterpoint .......................................................... 8

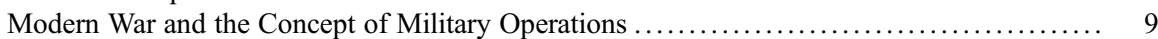

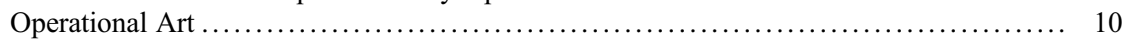

Operational Level of War ............................................... 11

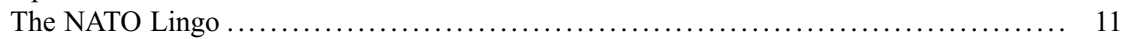

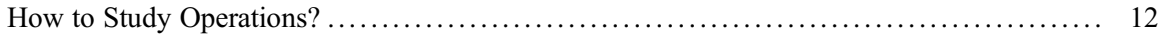

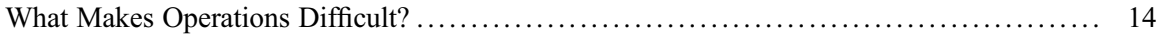

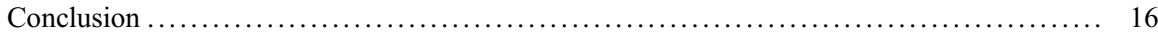

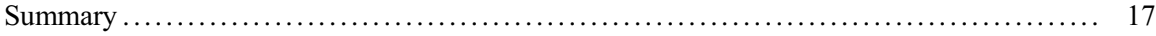

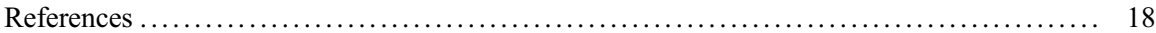

\section{Abstract}

Military operations can be a complex and cumbersome undertaking, involving millions of soldiers and tonnes of equipment. Even though war has been part of human experience for time immemorial, systematic thinking about how to prepare, conduct, and use military operations is nonetheless a rather new undertaking. This chapter explores the history of thinking about military operations, broadly defined, and narrows down on operations as the concept is used today.

After the historical exploration, the chapter investigates how military operations can be studied. In principle, there are four different ways to approach

\section{H. Høiback ( $\bowtie)$}

Norwegian Armed Forces Museums, Oslo, Norway

e-mail: hahoiback@forsvaretsmuseer.no 
operations as a field of study. The most common methods are the historical method and operations research, i.e., making heuristic models of reality. Game theory and axiomatic foundationalism are the other two but are far less used than the former two.

The development of modern military thinking notwithstanding, it is still difficult to convert military power to strategic gains, and the latter part of the chapter explains why. Military commanders and planning groups do not always get the what and why from the political level, making it difficult to find the how. Military operations are also intrinsically difficult because your opponent will try to make it difficult for you. The concept of an operational level of command is also problematic, since it tends to do the opposite of what is intended. Instead of pulling tactics and strategy closer together, it tends to push them apart. And finally, the word "art" in "operational art" is perhaps also an unfortunate misnomer?

\section{Keywords}

Military operations $\cdot$ Military thought $\cdot$ Strategy $\cdot$ Operational Art $\cdot$ Clausewitz $\cdot$ Epistemology

\section{Introduction}

From time immemorial, war has been part of human experience. It has also many ramifications, not only for those directly involved. According to Edward Mead Earle: "[war] is like a great tempest which blows upon us all, mingles with the church organ, whistles through the streets, steals into our fireside" (Earle 1944: vii).

War can thus be studied from many different directions, and with many different purposes, as has also been pointed out in the introductory chapters of this handbook (Sookermany 2020a, b). The aim of this chapter is to investigate the military core of war, i.e., where military men and women more or less skillfully put people, equipment, and movements together in order to overcome an enemy or solve a political problem. Our topic is not the causes of war, the preparation for war, or unintended consequences of war, but thoughts about how to use military means in order to reach goals beyond war itself. This chapter will introduce the concept of military operations.

Etymologically the word "operation" has its origins in the Latin word operari, which means to work or to labor. Typically, the word is used to denote the effort to reach rather complicated goals, usually implying planning, several subtasks, and considerable expertise. To fight wars is archetypically a venture that requires extensive planning, dividing the work into several different subtasks, and then aggregating the results.

Military campaigns or activity are usually done in close coordination with other means, such as, for instance, diplomacy and economy, but the concept of "military 
operation" usually denotes the military side of that process. Strategy, on the other hand, denotes how military operations can be used to reach political goals.

In an effort to flesh out the concept of military operations, we will begin this chapter by looking into the history of thinking about military operations, broadly defined. As we will see, operations, as we use the term today, is a rather new concept, but people have obviously thought about how to use military means efficiently long before the word became commonplace in the military vernacular. Thereafter we will narrow down on operations as the concept is used today. Here we will depict that the concept of operation has fanned out in three rather different directions: as a process, a particular skill, and a level of command. We will close the chapter with a short introduction to how to study military operations, and then look into some of the reasons why it is still rather difficult to succeed with military operations, i.e., to reach political goals with, among other things, military means.

\section{A History of Military Thought: A Long and Winding Road Towards a Conceptualization of Military Operations}

You can of course skin the cat in many ways. It is particularly so with such a multifarious "cat" as military operations. Personally, I prefer to use history as a vehicle to explore the nature and development of military operations. Not because we will relive past experiences, but because studying the past gives us an impression of how the concept has evolved, and of those challenges it was developed to handle. It also gives us a feeling of how military thinking, and acting, always are closely related to thinking and acting more generally. By using history to explore military operations, we are also reminded that the way we do and think military operations today may not be eternally relevant.

\section{The Ancient Roots}

As long as war has existed, people have commemorated fallen heroes and praised their deeds, but it is not until ca. 400 B.C., in China, that we find the first attempts to systematize knowledge of past wars in order to win the next (Creveld 2000, p. 20). Almost three millennia later, Sun Tzu's The Art of War is still widely read. The current military popularity of the book is probably best explained by the spread of low-intensity warfare, and that the military canon of Europe is mainly centered on large inter-state wars, and offers few answers to contemporary questions the way Sun $\mathrm{Tzu}$ apparently does. Furthermore, the fact that The Art of War is short and crisp without military jargon, certainly helps to explain its popularity. It is a "compact guide" which presents its conclusions readily to the reader, not a "torturous and tortuous reasoning process," as, for instance, is Clausewitz's On War (Handel 1996, p. 22).

However, Sun Tzu's aphorisms and lack of technical trivialities have also made the book's practical value questionable for later generations. To what extend will 
truisms, such as: "To effect a retreat that cannot be overtaken, employ unmatchable speed" (Sun Tzu 1994, p. 191), actually help you in the field? If Sun Tzu, if he ever lived, never cared much about the practicalities of war, it is perhaps a greater problem to our own time that he did not care much about politics either: "One might win battles and even campaigns with Sun Tzu, but it is difficult to win a war by following his principles. The reason for this is that Sun Tzu was never interested in shaping the political conditions, because he lived in an era of seemingly neverending civil wars." (Herberg-Rothe 2007, p. 8).

Even if the Greek contemporaries of Sun Tzu invented philosophy as we know it today, their military peers were little concerned with the systematization and justification of military knowledge. Thucydides (c.460 - c.400 BC), an experienced officer himself, even makes a point out of the fact that the bellicose Spartans were virtually anti-intellectual when it came to war: "We are trained to avoid being too clever on matters that are of no use - such as being able to produce an excellent theoretical criticism of one's enemies' dispositions, and then failing in practice to do quite so well against them." (Thucydides 1972, p. 85).

The Roman Flavius Vegetius came in the late fourth century A.D. quite close to becoming what we would now recognize as a military theorist, but even he seems to follow what may be called the "Aristotelian method of enquiry," which depends on some sort of "intuition of the essential properties and natural purposes of things" (O'Hear 1989, p. 12). Vegetius was thus not really a theorist after all. His aim was not really to explain anything but to prescribe actions and military tricks of the trade in a "take-my-word-for-it" type of manner.

\section{The Military Renaissance}

Some would perhaps judge it unfair to jump directly from Vegetius to Niccolò Machiavelli (1469-1527), leaving almost 1000 years of military contemplation in the dark, but when Machiavelli wrote The Art of War, he not only mimicked the structure of Vegetius' De re militari but whole portions of the book were reproduced without much modification.

You would be excused for thinking that the invention of gunpowder had invalidated Roman experiences, but Machiavelli was of another opinion: "[T]he invention of artillery is no reason, in my opinion, why we should not imitate the ancients in their military discipline and institutions, as well as in their virtü" (Machiavelli 1965, p. 99). To Machiavelli's generation, historical studies had great value, because history was regarded as: "an extensive testing ground of a relatively limited number of military systems" (Gat 2001, p. 3). This was so because man and society remained "in essence" the same, technological inventions notwithstanding, and lessons of history can thus be distilled from it. History offered "good examples to follow and bad examples to avoid" (Burke 2000, p. 182). 


\section{The Military Enlightenment}

If we are to believe the ancient Greek philosopher Socrates, a life that is unexamined is not worth living. The yearning for understanding, without any ulterior motives or practical aims, is apparently a crucial part of being human (Brunschwig and Lloyd 2000, p. 72). The post-renaissance generation, however, did not long for a disinterested philosophical contemplation of the world's order and harmony, but for an improvement of life. Early modern man started to use his knowledge instrumentally; he had become a problem solver, a person not previously seen in history. By the eighteenth century, useful and practical knowledge had not only become respectable but highly valued (Burke 2000, p. 110).

The first significant military thinker, and practitioner, who stood on the shoulders of people like Copernicus, Galileo, Bacon, and Descartes, if somewhat unwittingly, was the Italian General Raimondo de Montecuccoli (c.1609-1680). Due to several years of forced inactivity, as a Swedish prisoner of war, he became in many ways the first proto-scientific military writer we know (Barker 1975, p. 5). His way of contemplating had a certain scientific gist:

I have attempted within this concise framework, to encompass the vast areas of the only science vital for the monarch, and I have done my utmost to discover basic rules on which every science is based. . . and, having considered the entire range of world history, I dare to say that I have not found a single notable military exploit which would not fit in with these rules. (Rothenberg 1986, p. 63)

Montecuccoli marked a significant movement away from the previous "copy-a greatmodel" tradition, or rather the apprentice master relationship, and endeavored instead to "lay down laws on an empirical basis" (Barker 1975, p. 6). By that Montecuccoli "offered the foundations of a general theory of war" (Gat 2001, p. 15).

The Enlightenment developed an enormous self-confidence in the human mind's ability to catch the eternal laws that apparently govern every one of us. The rise of embryonic social science, or civil philosophy, as in Thomas Hobbes' De Cive, indicated that even volatile human beings could be dissected by modern scientific methods: "Ever since the great revolution which produced modern science there has been a hope that a science of society would be created on a par with the sciences of nature" (Cohen 1994, p. 101). The Enlightenment's belief in the ability of humans to know and manipulate the surroundings also had a strong influence on military thinking. Both the enemy and the chaos of war could at last be overcome by scientific methods.

The military Enlightenment was characterized by four inclinations: totality, "pioneerism," reductionism, and scientism. We will have a quick look at each of them.

Totality, in this context, means that in the early phase of the military Enlightenment, most theorists opted to cover all aspects of war, "down to the smallest details" (Gat 2001, p. 34). Hence, it was not unusual to find treatises dealing with everything from the preferred fabric of woolen blouses to formations of pikemen and the nature 
of war. But during the Enlightenment, this totality began slowly to crack into subdisciplines.

The second inclination, pioneerism, indicates that while Isaac Newton (16421726) had few problems admitting that he was a dwarf standing on the shoulder of giants, his military contemporaries fiercely denied any predecessors worthy of the name. Jacques de Guibert (1743-90) stated, for instance, that his Essai général de tactique, published in 1772, was the masterpiece that finally created a science of war (Gat 2001, p. 46). Many military treatises had already been published, but this was still a pre-paradigmatic undertaking and every thinker was thus on his own so to speak. Much like a modern-day novelist, they were fully aware of other peoples' works, but they did not feel like members of a collegium that together added stones to a common theoretical edifice.

The next inclination of the military Enlightenment is reductionism. Presumably all past masters of the art of war, for instance, Caesar (100-44 BC) and Gustavus II Adolphus (1594-1632), had adhered to the same general rules of war, however unwittingly. Hence, the rules had tacitly existed, even if no one had yet managed to pin them down in theory. The idea was that the theory of war could be derived from the full scope of historical observation, from Homer until the present day. The principles of war were nuggets of gold, ready to be revealed by anyone able to wash away all peculiarities and apparent irregularities. This sentiment has outlived the Enlightenment itself: "It certainly cannot be a mere coincidence that we always find identical principles underlying the ways of acting of all the great captains; for that reason alone we already have the right to believe that their successes have been due precisely to their agreement in the application of these principles" (Alger 1982, p. 71).

The last inclination, the scientism of military thought, to use a mildly anachronistic term, is also quite visible in this period. Newtonian science, with maximum mathematical precision, stood out as the era's crowning intellectual achievement, and most thinkers opted for something resembling it, even if less formalized: "The aim - so far as it was possible - was to bind assent in iron chains of mathematical and logical deduction, seeking to guide the mind along from necessary truth to necessary consequence" (Shapin 1996, p. 116). This general trend was enhanced by a particular trend within the military art as well. Marshal Sébastien Le Prestre de Vauban (1633-1707), the master of fortification and siegecraft during the reign of king Louis XIV (1638-1715), had shown the enormous potential of the esprit géométrique in war (Gat 2001, p. 37). With reference to Vauban, Frederick the Great (1712-1786) stated that: "The art of conducting sieges has become a profession like those of the carpenter and shoemaker. The rules are so well known that it is not worth the trouble of repeating them" (Frederick the Great 2005, p. 72).

\section{The Birth of the Paradigm}

It was a former Swiss bank clerk, Antoine de Jomini (1779-1869), that managed to tie all the loose threads of the military enlightenment into a rather comprehensive 
whole. Before Jomini, military thinking was typically pre-paradigmatic and preprofessional. After Jomini, military theorists implicitly agreed on what a proper military question was. Jomini established something resembling a Kuhnian paradigm, which to a great extent ended the interschool debate about the fundamentals of military science. According to Thomas S. Kuhn (1922-1996), a paradigm provides scientists "not only with the map but also with some of the directions essential for map-making" (Kuhn 1996, p. 109). Jomini marked the end of the military polymath and the self-taught entrepreneurial officer. Personal experience alone no longer qualified as science. Gradually, military science became a profession of its own, containing specialized concepts and vernacular, and where different contributors could lean on each other's work, without having to establish the field of knowledge from ground up every time.

According to Jomini, the art of war "consists of five purely military branches, viz.: Strategy, Grand Tactics, Logistics, Engineering, and [Minor] Tactics" (Jomini 1971, p. 13). Strategy decides where to fight by directing "armies to the decisive points of a zone of operations," while grand tactics are about handling the big battalions by "making good combinations preliminary to battles, as well as during their progress." Minor tactics are then how to win all the small engagements that together add up to a major win on the battlefield (Jomini 1971, p. 178). In other words: Strategy picks the place to fight and allocates means and forces to do so, grand tactics arrange main military assets on the field of battle, and minor tactics guide the actual fighting on the pitch. In addition, come logistics, i.e., the science of how best to bring all the necessary stuff to the battlefield, and engineering, i.e., the science of constructing what the troops need to move and survive.

In addition to these five, there is also, according to Jomini, a sixth discipline, "more naturally and intimately connected with the profession of a statesman than with that of a soldier," namely: "Diplomacy in its relation to war" (Jomini 1971, p. 13). If strategy deals with where to fight, statesmanship in its relation to war deals with when to fight, and against whom. These are important questions indeed, but "useless to a subordinate general" (Jomini 1971, p. 13). The only officer that needs to be bothered with policy is the general at the very top of an army. The rest should only focus on the pieces on the chessboard so to speak. The political context is just as irrelevant for the colonels, as it is for the chess player.

Jomini's six disciplines are, to this day, the bedrock of military education and expertise. If there is such a thing as a military paradigm, Jomini is in the dead center. The first two of the disciplines, strategy and grand tactics, are obviously related to operations and operational art, as we use the terms today, and which we will return to.

By establishing this paradigm, Jomini had finally given us a bulletproof method to succeed in military operations:

It is true that theories cannot teach men with mathematical precision what they should do in every possible case; but it is also certain that they will always point out the errors which should be avoided; and this is a highly-important consideration, for these rules thus become, in the hands of skilful generals commanding brave troops, means of almost certain success. 
The correctness of this statement cannot be denied; and it only remains to be able to discriminate between good rules and bad. In this ability consists the whole of a man's genius for war. (Jomini 1971, p. 323)

This was good news indeed. Perhaps too good to be true?

\section{A Counterpoint}

The Prussian philosopher of war, General Carl von Clausewitz (1780-1831) is still the most prominent thinker who has tried to break with the Jominian paradigm. According to Clausewitz, there are several reasons why it is impossible for war to be turned into science, or into an art.

First, moral factors, including deeply human traits such as hatred, fear, and courage, will always be present and disrupt rational calculation. Secondly, war also includes positive reaction, or lebendige Reaktion in German. War is always a struggle between people, with reverse intentions and "the very nature of interaction is bound to make it unpredictable" (Clausewitz 1976, p. 139). There can thus not be a recipe for victory. Both sides cannot win. The third reason was the pertinent uncertainty of all information, or the fog of war, which compels the commander to trust his talent or luck, not just his skills.

Clausewitz consequently pointed out that both art and science can be red herrings in the hunt for the proper analogy: "we must go on to say that strictly speaking war is neither an art nor a science. To take these concepts as a point of departure is misleading in that it has unintentionally caused war to be put on a par with other arts or sciences, resulting in a mass of incorrect analogies" (1976, p. 149). To Clausewitz, it is something rather mundane that resembles war the most: "From the very start there is an interplay of possibilities, probabilities, good luck and bad that weaves its way throughout the length and breadth of the tapestry. In the whole range of human activities, war most closely resembles a game of cards" (1976, p. 86).

In a card game, the presence of the opponent is sine qua non. You never forget your opponent when playing poker. It is, unfortunately, very easy to forget him when making war, at least that he also has plans and intentions.

The sum total of war's moral factors is that it is impossible to "construct a model for the art of war that can serve as a scaffolding on which the commander can rely for support at any time" (Clausewitz 1976, p. 140). A positive doctrine, or in Clausewitz's own words Eine positive Lehre à la Jomini, is unattainable.

Apparently, Clausewitz had reached a dead end. Why should anyone bother to read his works if he had nothing to offer the military man?

Clausewitz pointed out two different solutions. The first was the most straightforward. He claimed that the problems identified did not apply equally to all elements of war: "What is most needed in the lower ranks is courage and selfsacrifice, but there are far fewer problems to be solved by intelligence and judgment" (Clausewitz 1976, p. 140). Consequently, "tactics will present far fewer difficulties 
to the theorists than will strategy." (Clausewitz 1976, p. 141). Indeed, it would not take a philosopher, such as himself, to figure out tactics: "Elementary tactics', [Clausewitz] had declared in his 1804 notes, 'are studied ten times more often and much better - by sergeants'." (Strachan 2007, p. 118).

Clausewitz's second way out, i.e., the solution to the problems that remained at the higher level of war, is more intriguing: "The second way out of this difficulty is to argue that a theory need not be a positive doctrine, a sort of manual for action." (Clausewitz 1976, p. 141). Instead he regarded theory as an aid for better thinking:

\begin{abstract}
Theory will have fulfilled its main task when it is used to analyze the constituent elements of war, to distinguish precisely what at first sight seems fused, to explain in full the properties of the means employed and to show their probable effects, to define clearly the nature of the ends in view, and to illuminate all phases of warfare in a thorough critical inquiry. Theory then becomes a guide to anyone who wants to learn about war from books: it will light his way, ease his progress, train his judgment, and help him to avoid pitfalls. (Clausewitz 1976, p. 141).
\end{abstract}

To Clausewitz, policy is also relevant for everyone in uniform, not only for the general. If the officers forget the political goal, they can win all the battles, but still lose the war, or rather, not manage to reach the political goal. This is a crucial point in Clausewitz's philosophy of war. The waging of war has to adopt to policy, and policy must adapt to its chosen means: "War in general, and the commander in any specific instance, is entitled to require that the trend and designs of policy shall not be inconsistent with these means. That, of course, is no small demand" (Clausewitz 1976, p. 87).

\title{
Modern War and the Concept of Military Operations
}

Viewed in the rear-view mirror, the Napoleonic wars, where both Jomini and Clausewitz had seen action, seem like one prolonged struggle that finally ended at Waterloo in 1815. But that was not the participants' impression. For Napoleon, the next big battle should always be the last, and the one that forced the enemy to the negation table, on his terms (Nolan 2017, p. 12).

When the American Civil war broke out in 1861, everyone expected that this war would also be decided by one big battle. Not one of the gigantic Napoleonic size, but big enough for both parties to come to their senses. It soon became clear, however, that this war would not be over in one battle or one summer campaign. Later in life, the then famous General Ulysses S. Grant (1822-1885) was asked about his view on Jomini. Grant's reply was that he had not paid the great theorist much attention because: "The art of war is simple enough; find out where your enemy is, get at him as soon as you can, strike at him as hard as you can, and keep moving on" (Gat 2001, p. 292). "Keep moving on," is the key phrase. A battle won or lost is just a comma in a longer story. Not a punctuation mark.

In the wake of the Russo-Japanese War (1904-1905), and particularly The First World War, that also evolved into a Russian civil war, the Russians also noticed that 
something important had happened to the art of war. The vast spaces of modern war, and the astronomic numbers of soldiers and equipment involved, made another military skill necessary, in addition to tactics and strategy. You needed operations in between, so to speak. As stated by the Chief of Staff of the Red Army, General Mikhail Tukhachevskii (1893-1938): "Since it is impossible with the extended fronts of modern times to destroy the enemy's army at a single blow, we are obliged to try to do this gradually by operations which will be more costly to the enemy than to ourselves" (Naveh 1997, p. 183). In other words, the desired outcome of a battle or an engagement, or even a campaign, can rarely be victory, but an improved position to stage the next battle or operation.

\section{Operational Art}

Tactics is about winning the battles, and strategy is about winning the war. The problem is that you can win all the battles but still lose the war. Particularly in modern wars, where the distances and numbers involved may be gigantic, or the political goal ill-defined or rather blurry, you may thus need a steppingstone between tactics and strategy in order to succeed.

Usually it is the Russian General and military writer Alexander Svechin (18781938) that gets the honor of pinning this stepping stone on paper. He called it "operational art" and stated: "Studying the methods of conducting an operation is a job for operational art [...] On the basis of the goal of an operation, operational art sets forth a whole series of tactical missions and a number of logistical requirements" (Ydstebø 2012, pp. 421-425).

This idea can be illustrated by a simple model:

$\hookleftarrow$ Operational planning and backward engineering

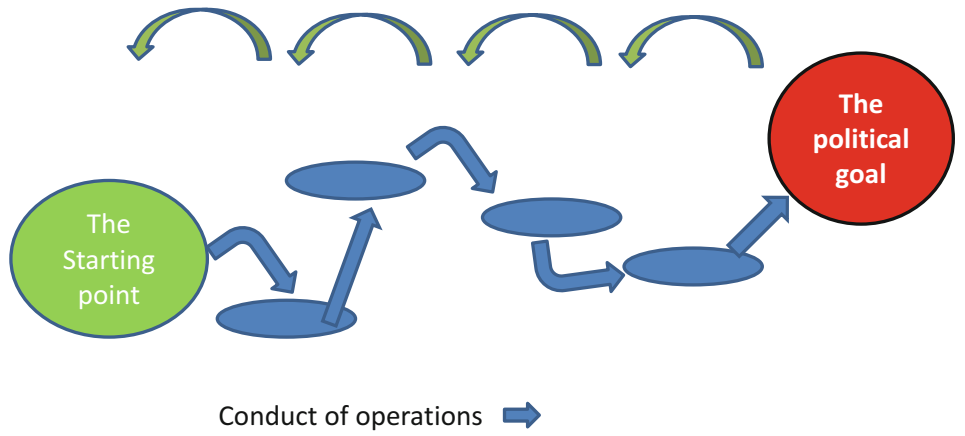

Simply put, Napoleon saw only one of the blue ovals at a time, hoping it would be the last one. Grant, on the other hand, saw, together with the President, the red circle, and tried to figure out where to put the stones to ford the river. And, finally, the Russians put these insights into words and doctrine. 
After the Second World War, and particularly after the debacle in Vietnam, Western military thinkers tried to pick the best from German and Russian military thinking.

General Tukhachevskii had in 1926 indicated that you don't only needed a new military skillset, operational art, but also a new level of command: "Battle in modern operations stretches out into a series of battles not only along the front but also in depth until that time when either the enemy has been struck by a final annihilation blow or the offensive forces are exhausted. In that regard, modern tactics of a theatre of military operations are tremendously more complex than those of Napoleon. And they are made even more complex by the inescapable condition mentioned above that the strategic commander cannot personally organize combat" (Naveh 1997, p. 10). In other words, you sometime need someone between the strategic commander and the battle captain.

\section{Operational Level of War}

Even though the Napoleonic Wars, The American Civil War, and The First World War all suggested that something was needed in addition to tactics and strategy, it took quite a while for the operational level as a distinct field of knowledge to mature in the western world. It was as late as 1982 that the publication of US Army Field Manual (FM) 100-5, Operations, introduced the concept of an operational level of war, in addition to the tactical and strategic level (Naveh 1997, p. 12). And it was not until the 1986 revision of the 1982 FM 100-5 that the concept of "operational art" entered American doctrine.

The main reason for adapting operational art, and introducing a new level of war was, as mentioned, to cope with the vast numbers and distances involved in modern war. But there was also another reason, which does not depend directly on scale and size. As we never make war for wars own sake, but to reach political goals, we need operational art to assist strategy in order to reach something positive, i.e., our political goals, with something disruptive, i.e., military means. The operational level of command and operational art are necessary when the military side of the conflict becomes so complex that it can no longer be managed by the strategic command directly.

Now we have walked a rather long and winding road from Sun Tzu to US Army Field Manual (FM) 100-5, and the time has come to take stock. Not all readers of this chapter live in a member state of NATO, but the way NATO defines core concepts is not very far from the global military lingua franca, so to speak.

\section{The NATO Lingo}

On its most generic level, NATO defines operations as: "A sequence of coordinated actions with a defined purpose" (NATO 2019). In the NATO vernacular, an operation 
is thus a military activity that contributes to attaining a goal - an end state - as part of a wider approach that also includes nonmilitary actions (NATO 2019).

This is the first denotation of "operations." It is the use of military means to reach a defined purpose. This in contrast to other military activities, as, for instance, administration, maintenance, and recruiting, which are not military operations, but means to support operations.

The second denotation of "operations" is connected to the concept of "operational art," which is: "[t]he employment of forces to attain strategic and/or operational objectives through the design, organization, integration and conduct of strategies, campaigns, major operations and battles" (NATO 2019), where a campaign is a "set of military operations planned and conducted to achieve a strategic objective" (NATO 2019).

The third denotation of "operations," or rather "operational," is connected to a certain level of command. Between the tactical and the strategic level of command, there exists an operational level of command, which is: "[t]he level at which campaigns and major operations are planned, conducted and sustained to accomplish strategic objectives within theatres or areas of operations" (NATO 2019). This is usually the level of command where you find generals and admirals, who, as a rule, command joint and combined forces, i.e., operations with forces from more than one service (joint), and from more than one nation (combined).

\section{How to Study Operations?}

The inner core of military activity, operations included, are, as stated by Clausewitz, human beings. In other words, military operations may be studied along the same lines as any other science studying human beings. And, as again stated by Clausewitz, since fighting is "a trial of moral and physical forces through the medium of the latter" (1976, p. 127), the study of operation also has to include the study of the use of technology and physical force.

The study of operations and operational art is thus not very different from the methods used in social sciences more generally, where it is impossible to test your hypotheses in a laboratory. Such work can in principle be based on empirical evidence, i.e., induction, or on the laws of logic, i.e., deduction, or a combination thereof.

The outcome of induction and deduction can then be presented either qualitatively or quantitatively, or again as a combination thereof. Consequently, the production, presentation, and evidential support of studies of military activities can, at least for the sake of argument, be placed in this model (Høiback 2013): 


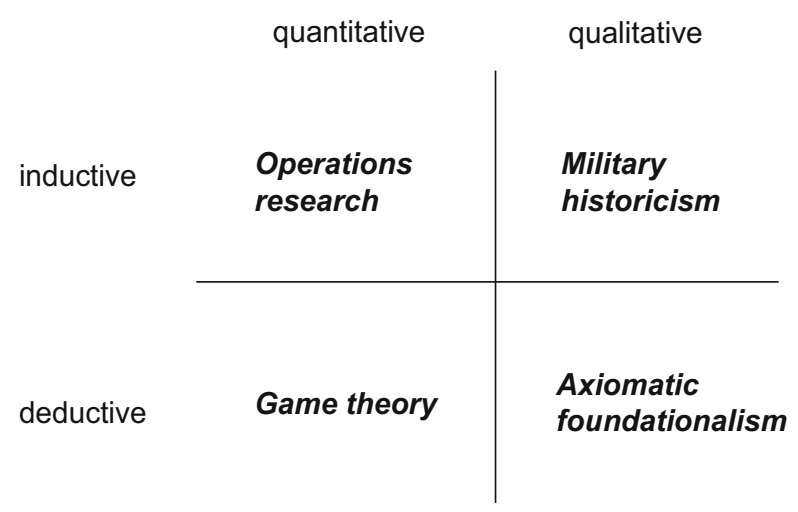

Different types of operations research are, roughly speaking, heuristic models of reality, often mathematical, that can be used to explain or foresee outcomes (Krepinevich and Watts 2015). Any system, such as the military, that can be modelled and broken down into smaller processes and structures can be explored by operations research. The limitation of the method is that it is fundamentally onesided and reduces war to quantifiable variants.

Game theory, on the other hand, starts with mathematical models to describe interaction, where the symbolic language of mathematics allows for precision unattainable for qualitative methods. The limitation of this method is that it assumes that the decision makers are rational, which is not always the case. Sometimes decision makers are angry, vengeful, or just tired.

The historical method is by far the most common way to study military operations. In many ways, military thinking is elaboration on history: "We have early adopted a comprehensive study of military history and confidently left the strategy as a logical result of the former" (Alger 1982, p. 85). Military history has indeed often been produced for the sake of practical utility, as stated by J.F.C. Fuller: "Unless history can teach us how to look at the future, the history of war is but a bloody romance" (Strachan 1983, p. 1).

The main limitation of the historical method is, of course, that the part of the history we study may have no relevance for the future. The times have changed too much. As Howard stated: "an unintelligent study of military history which does not take adequate account of these changes may quite easily be more dangerous than no study at all" (Howard 1981, p. 13). And as Strachan points out: "It is [also] well known that military history, when superficially studied, will furnish arguments in support of any theory or opinion" (Strachan 1983, p. 2).

So everyone studying military operations via the historical route has to study it in width, i.e., take into account how war has developed over a long historical period, in depth, i.e., to study it thoroughly, and in context, as "[w]ars are not tactical exercises writ large" (Howard 1981, p. 14), but part of something larger, i.e., the society.

And finally, axiomatic foundationalism is study based on higher and more fundamental truths. Euclid's classic Elements is a case in point, which starts with 
definitions, postulates, and axioms that cannot be proved, only accepted. If, or when, the axioms are accepted, the theorems in the rest of the book follow logically. The British military theoretician Sir Basil Liddell Hart's (1895-1970) theory of the "Man-in-the Dark" is a succinct military instance of this axiomatic way of thinking:

To understand the few essential principles of war, as distinct from the mass of precepts and reservations with which the teaching of it is usually overloaded, we must simplify it and reduce it to the essential elements which are true of any fighting, whether between two individual men or two great national armies. Let us therefore examine the principles which govern the combat of two individuals. From the course of action which is correct in their case we can deduce the essential principles, and can then proceed to apply the latter to the conduct of war. (Liddell Hart 1920, p. 473).

The limitation of this method is that the practical relevance of the starting axioms can be miniscule.

So far, we have investigated very generic ways to study military operations. However, there is something worth saying specifically about studying operations, operational art, and the operational level of war. It is often very difficult to stay in line, so to speak. It is very easy to be pulled down to tactics, where all the action is, or up to strategy and politics, where all the interesting people are. That is not to say of course that strategy and tactics are irrelevant for military operations, but that the latter tends to be ignored in the shadow of the former two. Hence, the good books about the operational level of war are few and far between. John Kiszely, Anatomy of a Campaign: The British Fiasco in Norway, 1940 from 2017 is one of the best and highly recommendable.

Even though operational art encompasses all kinds of military means, it is also important to remember that different domains and realms influence operations in different ways. Operations on land are different from operations at sea. And in the cyberworld, the realm itself does not even exist independently of human actions. Such issues will be the subjects of the subsequent chapters in this section of the Handbook of Military Sciences.

\section{What Makes Operations Difficult?}

As the military operations since 2001 have demonstrated, it is, the introduction of operational art and the operational level of command notwithstanding, still difficult to convert military prowess and dexterity into strategic gains. Why is that?

First, operations are based on the feasibility of deducing military actions from the goals of policy, but, as pointed out by Professor Strachan: "All this [is] entirely logical, but it [begs] a very important question: what would happen if there were no strategic goals?" (Strachan 2013, p. 216). Perhaps policy and military action do not go as well together as we often think? As stated by General (r) Jim Mattis:

In some cases, I could see what our policymakers didn't want to happen-we didn't want Israel attacked, didn't want Iran with nuclear weapons or mining the Straits of Hormuz, and 
so on-but I couldn't find an integrated end state we were trying to achieve: What does it look like when we're done? (Mattis and West 2019, p. 194)

Generals could of course demand clear-cut end states from their political masters before they do anything, but that would be wishful thinking. Some problems are wicked. As stated by the former British Foreign Secretary Douglas Hurd to the journalist Max Hastings:

Your military friends, Max, should grasp the fact that often they won't get the clarity of
purpose, the fixed objectives they want. It may be necessary sometimes to take some action
simply to avert a humanitarian disaster, and worry later about what comes afterwards.
(Richards 2014: xi)

Military commanders and planning groups do not always get the what and why, and it is thus difficult to find the how.

Second, military operations are difficult because your opponent will try to make it difficult for you. Hence, you must subdue your opponent, in one way or another to succeed, but that is not the aim of the encounter, only a means. We fight battles in order to win, but we never fight wars in order to win, but in order to reach our political goals. Wars are not battles written large. Lucky are the politicians that have generals who understand the difference, for as Richard Betts points out: "To paraphrase Clausewitz, the purpose of war is to serve policy, but the nature of war is to serve itself' (Betts 2000, p. 37). Operational art has, in other words, a tendency to succumb to the nature of war, i.e., to subdue the enemy, rather than serve its purpose, i.e., to reach the end state, if there is one. The tail wags the dog.

Third, the concept of an operational level of command is also problematic. According to Strachan, the reason why the operational level of war became important in the USA in the 1980s, was because especially the U.S. Army sought to regain its self-respect. In the 1950s and 1960s, nuclear strategy had predominated, with civilian thinkers leading the discourse, and in the 1970 s, the impression was that the U.S. Army had lost in Vietnam due to political meddling in military affairs. According to Strachan, with the introduction of an operational level of war, the U. S. Army created an area that was "a policy-free zone, in which military expertise was unfettered and where armies reasserted their authority over war's conduct" (Strachan 2013, p. 213).

Consequently, operational art, as practiced on the operational level of command, has a sinister tendency to do the opposite of what is intended. Instead of pulling tactics and strategy closer together, operational art tends to push them apart. The operational level of command, with its strong commanders and heavy HQ's, tend to unhinge political thoughts from military actions. If that happens, the political ambitions and the military action have no connection, and the operational level of war: "can be said to have destroyed strategy as it was" (Kelly and Brennan 2009, p. 86).

Since the USA introduced the operational level of war and adopted the concept of operational art rather simultaneously, it is easy to think that operational art takes 
place at the operational level, but that is not necessarily the case. Perhaps it is better to talk about an operational dimension of war, rather than an operational level? (Howard 1983).

Fourth, operational art is particularly difficult in insurgency and guerrilla warfare, where smashing the armed forces of the enemy is barely relevant at all. In those cases, brilliant operational art, in the sense of brilliant orchestrating of our own military means, can inadvertently cause us to drive much deeper into the quagmire than we would have found ourselves without any skillful operational art at all.

Fifth, and finally, the word "art" in "operational art" is perhaps a misnomer. Military thinkers rarely get tired of discussing whether waging war is an art or a science, or perhaps both. That discussion is, as already seen, a dangerous one, because both art and science can be done in isolation. What war can never be, however, is an isolated act. Wars and combat always involve other people and other minds. Too often, however, we tend to forget that, as pointed out by Sir Michael Howard (1922-2019): "[T] he complex problem of running an army at all is liable to occupy his mind and skill so completely that it is very easy to forget what it is being run for" (Howard 1981, p. 13).

To conclude this part: Thomas E. Ricks' statement, that 'an 'operational' level of war" does not really exist (Ricks 2011), indicates that levels of war are a social construction. They only exist to the extent that we think they exist. However, the concept of an operational level of war, and the skills necessary to cope with operations, i.e., the operational art, are conceptual tools that may come handy, particularly if the next war is against a near peer opponent. But as with all other tools, it is important to use them properly. If we use them to isolate operations from policy, rather than integrating the two closer, we are worse off than without them.

\section{Conclusion}

According to Sir Basil Liddell Hart: "In strategy, the longest way around is apt to be the shortest way home." (Liddell Hart 1967, p. 5). The aim of operations and operational art is to coordinate the practical military work necessary to walk the way pointed out by strategy to be the best way home, so to speak, and not get lost or starve to death on the way. This chapter has perhaps also been a rather long way around, but hopefully, you as the reader has found your way home, in the sense that you have a better grasp of the rather elusive concepts of military operations, operational art, and the operational level of war, or rather level of command, than you had when you left home.

We have met Carl von Clausewitz many times in this chapter. For god reasons. He is, somewhat flippantly perhaps, not only the best philosopher of war, but the only one. And he was also on the scent of pinning down operational art, as he wrote:

Strategy, in connecting these factors [geography, time and weather] with the outcome of an engagement, confers a special significance on that outcome and thereby on the engagement: it assigns a particular aim to it. Yet insofar as that aim is not the one that will lead directly to 
peace, it remains subsidiary and is also to be thought of as a means. Successful engagements or victories in all stages of importance may therefore be considered as strategic means. (1976, p. 143).

Here "strategy" could be read as "operational art," as operational art assigns particular aims to future tactical actions. Strategy is, in this perspective, "those objects that lead directly to peace" (Clausewitz 1976, p. 143). If tactics is about winning the battles, operational art is about conducting operations to gain the objectives set out by strategy to win the war in a way that will allow the government to win the peace, or rather to reach their political goals.

\section{Summary}

This chapter sheds light on the development of military operations. Military operations, as we use the term today, is a rather new concept, and the chapter starts out by investigating how the thinking about and conduct of military operations have evolved over the centuries.

As long as war has existed, people have commemorated fallen heroes and praised their deeds. However, it is not until ca. 400 B.C., in China, that we find the first attempts to systematize knowledge of past wars in order to win the next. Even if the ancient Greeks invented philosophy as we know it today, their military peers were little concerned with the systematization and justification of military knowledge. Not even the Romans developed a theory of military operations as we know it today. Niccolò Machiavelli's The Art of War was also not a systematized theory as we now understand the concept.

The first significant military thinker who benefited from a scientific worldview, however rudimentary, was the Italian General Raimondo de Montecuccoli. The ensuing military enlightenment was characterized by four inclinations: totality, "pioneerism," reductionism, and scientism. Antoine de Jomini (1779-1869) managed to tie all the loose threads of the military enlightenment into a comprehensive whole. The Prussian general and philosopher of war Carl von Clausewitz was the most prominent thinker who tried to break with the Jominian paradigm.

The vast spaces of modern war, and the astronomic numbers of soldiers and equipment involved, made another military skill necessary than those possessed by Napoleon. You need a steppingstone between tactics and strategy in order to succeed: operational art and an operational level of war.

Military operations may be studied along the same lines as any other science studying human beings. It can be based on empirical evidence, i.e., induction, or on the laws of logic, i.e., deduction, or a combination thereof. The outcome of induction and deduction can then be presented either qualitatively or quantitatively.

As the military operations since 2001 have demonstrated, even with the introduction of operational art and the operational level of command, it is still difficult to convert military prowess and dexterity into strategic gains. Military commanders and planning groups do not always get the what and why, and that makes it difficult to 
find the how. The concept of an operational level of command is also problematic. Operational art, as practiced on the operational level of command, has a sinister tendency to do the opposite of what is intended. Instead of pulling tactics and strategy closer together, operational art tends to push them apart.

\section{References}

Alger, J. I. (1982). The quest for victory: The history of the principles of war. Westport: Greenwood Publishing Group.

Barker, T. M. (1975). The military intellectual and battle, Raimondo Montecuccoli and the thirty years war. Albany: State University of New York Press.

Betts, R. (2000). Is strategy an illusion? International Security, 25(2), 5.

Brunschwig, J., \& Lloyd, G. E. R. (Eds.). (2000). Greek thought, a guide to classical knowledge. London: The Belknap Press of Harvard University Press.

Burke, P. (2000). A social history of knowledge from Gutenberg to Diderot. Oxford: Polity.

Clausewitz, C. (1976). On war. Princeton: Princeton University Press. (1832).

Cohen, I. B. (1994). Interactions, some contacts between the natural science and the social sciences. Cambridge, MA: MIT Press.

Creveld, M. (2000). The art of war, war and military thought. London: Cassell.

Earle, E. M. (Ed.). (1944). Makers of modern strategy: Military thought from Machiavelli to Hitler. Princeton: Princeton University Press.

Frederick the Great. (2005). Instructions for his generals (trans: Phillips, T. R.). New York: Dover Publications. (1748).

Gat, A. (2001). A history of military thought. Oxford: Oxford University Press.

Handel, M. I. (1996). Masters of war, classical strategic thought (2nd ed.). London: Frank Cass.

Hart, B. L. (1920). The 'man-in-the-dark' theory of war, the essential principles of fighting simplified and crystallised into a definite formula. The National Review, June.

Hart, B. L. (1967). Strategy (2nd ed.). London: Faber \& Faber.

Herberg-Rothe, A. (2007). Clausewitz's Puzzle. Oxford: Oxford University Press.

Høiback, H. (2013). Understanding military doctrine. London: Frank Cass.

Howard, M. (1981). The use and abuse of military history. Parameters, XI(1), 14. (1961).

Howard, M. (1983). The forgotten dimensions of strategy. In M. Howard (Ed.), The causes of wars. Cambridge, MA: Harvard University Press.

Jomini, A.-H. (1971). The art of war. Westport: Greenwood Press. (1838/1862).

Kelly, J., \& Brennan, M. (2009). Alien: How operational art devoured strategy. https://publications. armywarcollege.edu/pubs/2027.pdf

Krepinevich, A., \& Watts, B. (2015). The last warrior, Andrew Marshall and the shaping of modern American defense strategy. New York: Basic Books.

Kuhn, T. S. (1996). The structure of scientific revolutions (3rd ed.). Chicago: The University of Chicago Press. (1962).

Machiavelli, N. (1965). The art of war (trans \& ed: Wood, N.). New York: Da Capo Paperback. (1521).

Mattis, J., \& West, B. (2019). Call sign chaos - Learning to lead. New York: Random House.

NATO. (2019). The Official NATO Terminology Database. https://nso.nato.int/natoterm/Web.mvc

Naveh, S. (1997). In pursuit of military excellence - The evolution of operational theory. London: Frank Cass.

Nolan, C. J. (2017). The allure of battle - A history of how wars have been won and lost. New York: Oxford University Press.

O'Hear, A. (1989). Introduction to the philosophy of science. Oxford: Clarendon Press.

Richards, D. (2014). Taking command. London: Headline Publishing Group. 
Ricks, T. E. (2011). Why I don't believe there is really such as thing as an 'operational' level of war. Foreign Policy. https://foreignpolicy.com/2011/02/17/why-i-dont-believe-there-is-really-suchas-thing-as-an-operational-level-of-war/\#

Rothenberg, G. E. (1986). Maurice of Nassau, Gustavus Adolphus, Raimondo Montecuccoli, and the "military revolution" of the seventeenth century. In P. Paret (Ed.), Makers of modern strategy. Oxford: Clarendon Press.

Shapin, S. (1996). The scientific revolution. Chicago: University of Chicago Press.

Sookermany, A. M. (2020a in press). Military sciences - The field. In A. M. Sookermany (Ed.), Handbook of military sciences. Cham: Springer.

Sookermany, A. M. (2020b in press). Philosophy of military sciences. In A. M. Sookermany (Ed.), Handbook of military sciences. Cham: Springer.

Strachan, H. (1983). European armies and the conduct of war. London: Routledge.

Strachan, H. (2007). Clausewitz's on war: A biography. New York: Atlantic Monthly Press.

Strachan, H. (2013). The direction of war - Contemporary strategy in historical perspective. Cambridge, UK: Cambridge University Press.

Sun Tzu. (1994). Art of war. Boulder: Westview Press. (ca. 400 BC.)

Thucydides. (1972). History of the Peloponnesian war. London: Penguin. (ca. 410 BC.)

Ydstebø, P. (2012). Fellesoperasjoner og operasjonskunst. In H. Høiback, \& P. Ydstebø (Eds.), Krigens vitenskap - en innføring i militcerteori. Oslo: Abstrakt forlag.

\section{Further Reading}

Baylis, J., Wirtz, J., Gray, C. (Eds) (2018). Strategy in the Contemporary World 6.edt. Oxford: Oxford University Press.

Bond, B. (1996). The Pursuit of Victory from Napoleon to Saddam Hussein. Oxford: Oxford University Press.

Echevarria II, A. J. (2017). Military Strategy: A Very Short Introduction. Oxford: Oxford University Press.

Freedman, L. (2015). Strategy: A History. Oxford: Oxford University Press.

Frieser, K-H. (2005). The Blitzkrieg Legend. Annapolis: Naval Institute Press.

Gray, C.S. (1999). Modern Strategy. Oxford: Oxford University Press.

Heuser, B. (2010). The Evolution of Strategy: Thinking War from Antiquity to the Present. Cambridge University Press.

Keegan, J. (1993). A History Of Warfare. London: Hutchinson.

Luttwak, W. (2002). Strategy: The Logic of War and Peace. Enlarged and revised, Harvard University Press.

NATO. (2017). NATO Standard, AJP-01, Allied Joint Doctrine, Edition E Version 1.

Olsen, J.A \& Creveld, M.V. (Eds). (2010). The Evolution of Operational Art: From Napoleon to the Present. Oxford: Oxford University Press.

Stone, J. Military Strategy (2011). London: Continuum. 
Open Access This chapter is licensed under the terms of the Creative Commons Attribution 4.0 International License (http://creativecommons.org/licenses/by/4.0/), which permits use, sharing, adaptation, distribution and reproduction in any medium or format, as long as you give appropriate credit to the original author(s) and the source, provide a link to the Creative Commons license and indicate if changes were made.

The images or other third party material in this chapter are included in the chapter's Creative Commons license, unless indicated otherwise in a credit line to the material. If material is not included in the chapter's Creative Commons license and your intended use is not permitted by statutory regulation or exceeds the permitted use, you will need to obtain permission directly from the copyright holder.

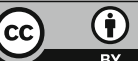

